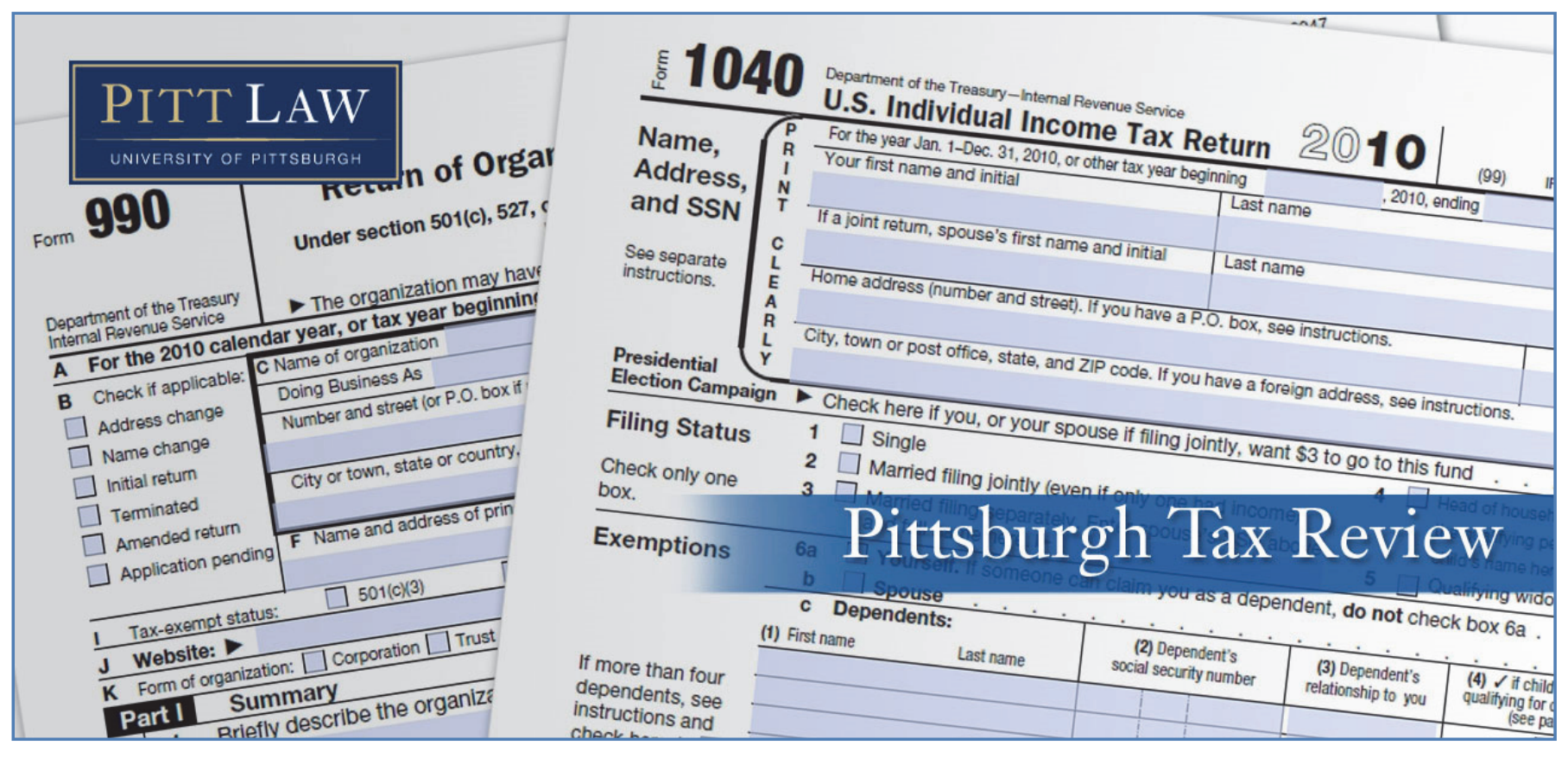

Volume 17 (2020) | ISSN 1932-1821 (print) 1932-1996 (online)

DOI 10.5195/taxreview.2020.114 | http://taxreview.law.pitt.edu

\title{
PRIVATE OPERATING FOUNDATION REFORM AND \\ J. PAUL GETTY
}

\section{Khrista McCarden}

\section{(c) EY-NC-ND}

This work is licensed under a Creative Commons Attribution-Noncommercial-No Derivative Works 3.0 United States License.

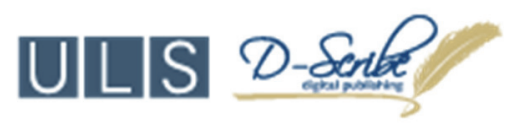

This journal is published by the University Library System of the University of Pittsburgh as part of its D-Scribe Digital Publishing Program, and is cosponsored by the University of Pittsburgh Press. 


\title{
PRIVATE OPERATING FOUNDATION REFORM AND J. PAUL GETTY
}

\author{
Khrista McCarden ${ }^{*}$
}

\section{INTRODUCTION}

The Tax Reform Act of 1969 ("the 1969 Act") established an arcane form of charitable organization called the private operating foundation. ${ }^{1}$ Essentially, a private operating foundation is a charitable organization exempt from income tax that in a hierarchical sense is situated between what is known as a public charity and a traditional private foundation. In other words, it is not publicly supported, as are public charities, and thus it is a private foundation; however, it does more than just make grants. ${ }^{2}$ This form has been subject to countless abuses ${ }^{3}$ and reform is necessary, especially in the context of private operating foundations that operate art museums ("private art museums"). A recent New York Times article reported that many perceive the ability of wealthy art donors to maintain control over artwork while also receiving tax benefits for varying degrees of public benefit as unfair. ${ }^{4}$ It is widely accepted that one of the fundamental policies underlying our federal tax system is the notion of fairness. ${ }^{5}$ Private art museums raise

\footnotetext{
${ }^{*}$ Hoffman F. Fuller Associate Professor of Tax Law, Tulane Law School; J.D. cum laude, Harvard Law School, 2003; A.B. Harvard College, magna cum laude. I am grateful to the Murphy Center of Tulane University, the participants of the Pittsburgh Tax Review Symposium, and the AALS Section on Nonprofit and Philanthropy law for helpful feedback, including Professors Ellen Aprill, Philip Hackney, Ray Madoff, and Dana Brakman Reiser.

${ }^{1}$ Tax Reform Act of 1969, Pub. L. No. 91-172, 83 Stat. 487 (1969).

${ }^{2}$ Exempt Organizations, Private Foundations, Fed. Tax Coordinator 2d (RIA) $₫$ D-7719. Forms.

${ }^{3}$ See, e.g., Patricia Cohen, Writing Off the Warhol Next Door, N.Y. TimeS (Jan. 10, 2015), http://www.nytimes.com/2015/01/11/business/art-collectors-gain-tax-benefits-from-private-

museums.html?_r=0 (describing how the private operating foundation Glenstone Museum is in close proximity to its owner's home and only hosted 10,000 total visitors from 2006 to 2013).

${ }^{4} I d$.

${ }^{5}$ See Liam Murphy \& Thomas Nagel, The Myth of Ownership: TaXes and Justice 12 (2004) ("[T]he task of the tax designer is to come up with a scheme that is both efficient and fair.").
}

Pitt Tax Review | ISSN 1932-1821 (print) 1932-1996 (online) DOI 10.5195/taxreview.2020.114 | http://taxreview.law.pitt.edu 
genuine concerns about whether any attendant public benefit resulting from them outweighs the perception of unfairness underlying them. ${ }^{6}$

Yet, the larger issues are whether private art museums are truly meeting a need that the government would otherwise have to meet and whether they are providing the broader public with a benefit. ${ }^{7}$ Access of people belonging to distinct groups is lacking. Pursuant to the regulations under $\S 501(\mathrm{c})(3)$ of the Internal Revenue Code ("Code"), private art museums must operate for public benefit, not private interests. ${ }^{8}$ This article provides a case study of one of the largest private operating foundations that has spanned the time from the 1969 Act through present, the J. Paul Getty Trust (the "Getty Trust"). The Getty Trust is the largest cultural and philanthropic organization dedicated to visual arts in the world. ${ }^{9}$ The Getty Trust operates, among other entities ${ }^{10}$ the Getty Museum, which includes the Getty Center and the Getty Villa. ${ }^{11}$

This case-study offers valuable insight as to necessary changes in the application of existing tax rules, rather than the commonly proposed reforms to the private operating foundation rules in their present form. These commonly proposed reforms are addressed and critiqued in this article to arrive at a better framework for a solution.

${ }^{6}$ DeP'T OF THE TREASURy, TAX REForm For FAIRNESS, Simplicity, AND ECONOMIC GROWTH: The TREasury Department RePORT to the PRESIDENT 16 (Nov. 1984), http://www.treasury.gov/ resource-center/tax-policy/Documents/tres84v1C-2.pdf (stating that " $[\mathrm{t}]$ he perception of fairness may be as important as fairness itself as a goal of tax policy.") [hereinafter TREASURY REPORT].

${ }^{7}$ See 26 C.F.R. § 1.501(c)(3)-1 (2017) (explaining that the term charitable includes "lessening the burdens of Government"). At the same time, charitable purposes include educational purposes, such as those of art museums. See 26 C.F.R. § 1.501(c)(3)-1 (2017) (explaining that the term charitable includes the "advancement of education"). Even state law recognizes, educational or religious organizations automatically satisfy the requirement to have a charitable purpose." Entities that can prove they are organized exclusively for educational or religious purposes automatically satisfy the second prong of the charitable immunity standard." Ryan v. Holy Trinity Evangelical Lutheran Church, 175 N.J. 333, 346 (N.J. 2003).

${ }^{8}$ Treas. Reg. § 1.501(c)(3)-1(d)(1)(ii).

${ }^{9}$ See Officers and Directors, GETTY, https://www.getty.edu/about/governance/officers.html (last visited July 16, 2020).

${ }^{10}$ See infra at 389-90.

${ }^{11}$ Id.

Pitt Tax Review | ISSN 1932-1821 (print) 1932-1996 (online)

DOI 10.5195/taxreview.2020.114 | http://taxreview.law.pitt.edu 


\section{TRAditional CRiticisms of PRivate ART Museums Miss the MarK}

Generally, criticism of private art museums has centered on complaints, such as lack of accessibility to the public due to location and hours. Senator Orrin Hatch's Senate Finance Committee investigation in 2015 resulted in three specific critiques of private art museums discussed in this section. ${ }^{12}$ Notably, the investigation did not address the underlying issue of whether these private art museums are operated for public benefit. It failed to consider whether certain private art museums simply do not provide a benefit to the general public, which includes those in lower socioeconomic classes, in those underserved areas and underprivileged schools, and those who are hospitalized or in elder care, among other distinct groups.

Museums raise important cultural and tax problems. In terms of overall scope, there are at least 35,000 museums in the United States, ${ }^{13}$ and over 800 million visits annually. ${ }^{14}$ In recent years, a "Renaissance" has occurred within the nonprofit sector in terms of the proliferation of private art museums. ${ }^{15}$ The vast majority of artworks in American museums were donated by private art collectors. Private art museums are not a new phenomenon and in fact date back to the nineteenth century in the United States. Once private art museums became increasingly popular in Europe, many high net worth individuals in the United States also desired to open their own. High-net-worth art collectors are increasingly curating their own private art museums, to which they may donate and receive charitable deductions. Surprisingly, these private art museums may only be a few steps from their homes. On the one hand, private art museums have several palpable contributions to society. For example, they encourage the public to

\footnotetext{
${ }^{12}$ Sen. Orrin G. Hatch, Letter to I.R.S. Comm. John Koskinen, May 17, 2016 (from Hatch as chair of the Sen. Fin. Comm. describing the committee investigation into private art museums), https://www .finance.senate.gov/imo/media/doc/Letter\%20to\%20IRS\%20on\%20Private\%20Museums.pdf.

${ }^{13}$ Institute of Museum and Library Services, Government Doubles Official Estimate: There Are 35,000 Active Museums in the U.S. (press release, May 19, 2014) https://www.imls.gov/news/ government-doubles-official-estimate-there-are-35000-active-museums-us.

${ }^{14}$ American Alliance of Museums, Museum Facts (2011) http://ww2.aam-us.org/about-museums/ museum-facts\#: :text=Museums\%20Are\%20Popular,(483\%20million\%20in\%202011).

${ }^{15}$ Evrim Oralkan, Private Art Becomes Public, OBSERVER (Mar. 3, 2016) https://observer.com/ 2016/03/private-art-becomes-public/.
}

Pitt Tax Review | ISSN 1932-1821 (print) 1932-1996 (online) DOI 10.5195/taxreview.2020.114 | http://taxreview.law.pitt.edu 
engage with art, and they preserve rare and influential fine art throughout decades. On the other hand, as the number of private art museums have grown over time, the number of abuses has also risen.

Indeed, some of the most well-known museums in the United States started off as private collections. Not only does the Getty Museum fall within this category, but also the Isabella Stewart Gardner Museum, Frick Collection, Barnes Foundation, and Morgan Library and Museum. The influence of these museums is immense, as they recognizably have shaped "the cultural landscape for generations." In 2017 there were forty-three private art museums in the United States, which was the second-highest number of such museums in the world. ${ }^{16}$

Unfortunately, neither the 1969 Act nor further legislation has ever defined when private interests overshadow public benefit such that taxexempt status should no longer be allowed. The idea of "private interests" is defined narrowly to mean spending the income for the use of private individuals. There simply is not enough guidance even for well-meaning private art museums.

In 2015, Senator Orrin Hatch investigated eleven private art museums and reported his findings in a letter to IRS Commissioner John Koskien in $2016 .{ }^{17}$ The eleven museums did not include the Getty Center or the Getty Villa, which comprise the Getty Museum operated by the Getty Trust. Senator Hatch concluded there were three main tax issues with private art museums: (1) donor's control over the board and assets, (2) lack of access by the public, and (3) private inurement. The investigation underscores a fundamental unfairness in the private art museum world: high-net-worth donors are afforded charitable deductions for art that is not really accessible to the public, and the governing board and officers are often stealing from the operating foundation as well given their sizeable endowment and investment income.

One must wonder whether such private art museums should be entitled to tax-exempt status at all. At the very least, perhaps greater restrictions are necessary to ensure they are in fact conferring a benefit upon the public.

\footnotetext{
${ }^{16}$ Michael Schnayerson, Inside the Private Museums of Billionaire Art Collectors, Town \& COUNTRY (Jan. 16, 2017) https://www.townandcountrymag.com/leisure/arts-and-culture/a9124/privatemuseums-of-billionaires/.

${ }^{17}$ Hatch, supra note 12.
}

Pitt Tax Review | ISSN 1932-1821 (print) 1932-1996 (online) DOI 10.5195/taxreview.2020.114 | http://taxreview.law.pitt.edu 
However, the benefit has to go beyond just affording access, as this study of the Getty Trust (and the Getty Center and Getty Villa it operates) shows. The real problem is not hidden or unmarked roads but rather large segments of society in the United States that will never be able to view the art collections due to circumstances beyond their control, such as underprivileged children, hospitalized, disabled, or elderly in nursing homes - to name a few categories. Unfortunately, the Senate Finance Committee did not propose any solutions to the problems it observed, nor did it resolve how to address the tension in the Code between public benefit and private interests in the context of private art museums. Senator Hatch's letter was not completely devoid of suggested reforms. For example, it was recommended that private art museums publicize the sufficiency of their charitable activities for taxexempt status or expand their programming and operations to further more tangibly their charitable purpose. These proposed reforms are woefully inadequate when looking at the multi-million dollar private art museums because the real problem is they are oversaturating a narrow segment of the public while leaving other sectors of the public devoid of any benefit. A case study of the Getty Trust illustrates the real problem.

\section{The J. PAUl Getty TRUST AND Private Operating FOUNDATION RULES}

When Jean Paul Getty died in 1976, he "left the largest estate ever subject to probate in the State of California." " The executors accounted for an estate worth $\$ 1,357,877,342.10{ }^{19}$ The Getty Museum received approximately $\$ 1.2$ billion of this amount since it was the residuary charitable beneficiary of the estate. ${ }^{20}$ The sale of Getty Oil Company led to an increase in the charitable bequest to the Getty Museum by $\$ 450$ million. ${ }^{21}$ The charitable purpose of the Getty Trust is the "diffusion of artistic and general knowledge." 22 The Getty Trust runs the following programs: the

\footnotetext{
${ }^{18}$ Estate of Getty, 143 Cal. App. 3d 455, 458 (Cal. Ct. App. 1983).

${ }^{19} \mathrm{Id}$.

${ }^{20} I d$.

${ }^{21} I d$.

${ }^{22}$ Press Release, Ten Years of Collecting at the J. Paul Getty Museum, GeTty (Sept. 24, 2007), http://www.getty.edu/news/press/center/ten-years oLcollecting.html [http://perma.cc/HN36-TNVS];
}

Pitt Tax Review | ISSN 1932-1821 (print) 1932-1996 (online) DOI 10.5195/taxreview.2020.114 | http://taxreview.law.pitt.edu 
Getty Center for the History of Art and the Humanities, the Getty Conservation Institute, the Getty Art History Information Programme, the Getty Center for Education in the Arts, the Program for Art on Film, and the Museum Management Institute. ${ }^{23}$ In 1985, a Grant Programme was added to the Getty Trust's charitable repertoire. ${ }^{24}$ As stated above, the Getty Trust runs the Getty Museum, which includes both the Getty Center and the Getty Villa. A close examination of the Getty Trust, which runs one of the most wellknown private art museums, specifically the Getty Center, evinces the larger problematic issues with private operating foundations that run private art museums. Prior to the COVID-19 pandemic, the Getty Center featured an exhibit entitled Painted Prophecy: The Hebrew Bible through Christian Eyes, which brought "manuscripts that explore the medieval Christian understanding of Hebrew Scripture into dialogue with the Rothschild Pentateuch, a masterpiece of the Jewish manuscript tradition. ${ }^{" 25}$ Historically, the Getty Center's significant artistic holdings have included works such as Irises, 1889 , by Vincent van Gogh. ${ }^{26}$

In a 1992 article, out of England, that profiled the Getty Trust's expenditures for the private art museums, Geraldine Norman reported that the Getty Trust would have to spend at least $£ 100$ million per year to comply with U.S. federal tax law requirements to maintain its tax-exempt status given its endowment of $£ 2.2$ billion. ${ }^{27}$

Norman went on to compare these expenditures to that of London's National Gallery, which stood at $£ 16$ million that year. ${ }^{28}$ Acknowledging that

Architecture, GETTY, http://www.getty.edulvisit/villa/architecture.html [http://perma.cc/WXW8-X49J] (last visited Apr. 27, 2020); Trust Indenture, GETTY, http://getty.edu/about/governance/indenture .html [http://perma.cc/AF88-GCKE] (last visited Apr. 27, 2020).

${ }^{23}$ See Geraldine Norman, A Little Tax Haven by the Sea: The J. Paul Getty Trust, InDEPENDENT (July 5, 1992), https://www.independent.co.uk/arts-entertainment/a-little-tax-haven-by-the-sea-the-jpaul-getty-trust-1531415.html.

${ }^{24} I d$.

${ }^{25}$ Painted Prophecy, GETTY, https://www.getty.edu/art/exhibitions/painted_prophecy/ (last visited July 17, 2020).

${ }^{26}$ Paintings, GETTY, https://www.getty.edu/art/paintings/ (last visited July 17, 2020).

${ }^{27}$ Norman, supra note 23.

${ }^{28} \mathrm{Id}$.

Pitt Tax Review | ISSN 1932-1821 (print) 1932-1996 (online) DOI 10.5195/taxreview.2020.114 | http://taxreview.law.pitt.edu 
the Getty Trust not only runs museums but also is a purveyor of art education, Norman compared its spending to that of the Courtauld Institute, Britain's top college of art history and noted it required a mere $£ 2.8$ million to operate the prior year. ${ }^{29}$ In fact, the only comparable spending was that of Oxford University, which expended $£ 179$ million the prior year, which is just under double what the Getty Trust had to spend. ${ }^{30}$

A comparison of these figures begs the question whether there is too much being spent on a charitable benefit aimed at such a small segment of society. For example, the parking to attend the Getty Center generally costs twenty dollars, and there is no street parking available. ${ }^{31}$ Despite free entry, many underprivileged individuals would not be able to afford the parking to visit. Moreover, public transportation is not a feasible option because most poverty in Los Angeles is concentrated in South Los Angeles. ${ }^{32}$ The journey time by public transportation from South Los Angeles to the Getty Center is approximately two hours. ${ }^{33}$ In addition, the hours are not conducive to visits after working hours, especially if using public transportation. ${ }^{34}$ Also, the elderly who reside in nursing homes would never have any opportunity to see the exhibits or artwork there. The same is true of those hospitalized with chronic illness. The issue is one of oversaturation of the stated charitable purpose. Funds should be expended on making the artwork and holdings more accessible, rather than continuing to acquire and collect prominent works that systemically disadvantaged segments of society will never see.

In order to accurately perceive the larger issues, one must examine the rules regarding private operating foundations. The first part of this section discusses the definition of a private operating foundation. It then discusses

\footnotetext{
${ }^{29} I d$.

${ }^{30} I d$.

${ }^{31}$ See Parking and Transportation, GETTY, https://www.getty.edu/visit/centerplan/parking .html (last visited July 17, 2020).

32 See Michael Matsunaga, Concentrated Poverty Neighborhoods in Los Angeles, ECoN. ROUNDTABLE (Feb. 9, 2008), https://economicrt.org/publication/concentrated-poverty-in-los-angeles/; see also Norman, supra note 23 (commenting upon the exorbitant spending of the Getty Trust, specifically the $£ 250,000$ per day on art while rioters [originating from South Los Angeles] tore the center of Los Angeles apart).

${ }^{33}$ Visit, GETTY, https://www.getty.edu/visit/center/plan/hours.html (last visited July 17, 2020) (showing Google Map directions by public transportation).

${ }^{34} \mathrm{Id}$.
}

Pitt Tax Review | ISSN 1932-1821 (print) 1932-1996 (online) DOI 10.5195/taxreview.2020.114 | http://taxreview.law.pitt.edu 
the public benefit requirement and the private inurement restriction applicable to both public charities and private foundations, which include both non-operating foundations and operating foundations. It then explains the five tax benefits associated with private operating foundations.

\section{A. Current Private Operating Foundation Requirements}

Under current law, a tax-exempt private operating foundation is any private operating foundation that meets the following criteria: (1) has been publicly supported for at least ten taxable years, or as of January 1, 1983 was an operating foundation; (2) the governing body of such foundation (i) consists of individuals at least $75 \%$ of whom are not disqualified individuals, and (ii) is broadly representative of the general public; and (3) at no time during the taxable year does such foundation have an officer who is a disqualified individual. ${ }^{35}$

A disqualified person is defined as one (1) who is a "substantial contributor" to the foundation; (2) who owns more than $20 \%$ of the total combined voting power of certain entities that are "substantial contributors"; or (3) who is a family member of any individual described in (1) or (2). ${ }^{36}$

A "substantial contributor" is defined pursuant to $\S 507(d)(2)$ of the Code which deals with the termination of private foundation status. In terms of the private foundation rules, a "substantial contributor" has contributed during life or after death more than $\$ 5,000$ to the private foundation provided the amount is greater than $2 \%$ of the total contributions and bequests received by the foundation during the given taxable year. ${ }^{37}$ If the private foundation is a trust, a "substantial contributor" is defined to include the settlor of the trust. ${ }^{38}$ There are also certain exceptions. For example, governmental units cannot be substantial contributors. ${ }^{39}$ For purposes of the rules above,

\footnotetext{
${ }^{35}$ I.R.C. $\S 4940(\mathrm{~d})(2)(\mathrm{B}) ;$ see also Technical and Miscellaneous Revenue Act of 1988, Pub. L. No. $100-647, \S 6204,102$ Stat. 3342 (adding a congressional note to the Internal Revenue Code which further defined the exact dates allowing for the constitution of an operating foundation).

${ }^{36}$ I.R.C. $\S 4940(\mathrm{~d})(3)(B)$.

${ }^{37}$ Id. I.R.C. $\S 507(\mathrm{~d})(2)(\mathrm{A})$.

${ }^{38} I d$.

${ }^{39}$ For a list of exceptions to this definition, see Treas. Reg. $\S 1.507-6(a)(1) ; \S 1.507-6(a)(2)$.
}

Pitt Tax Review | ISSN 1932-1821 (print) 1932-1996 (online) DOI 10.5195/taxreview.2020.114 | http://taxreview.law.pitt.edu 
"family" is defined pursuant to $\S 4946$ (d) of the Code and means specifically spouses, ancestors, lineal descendants, and spouses of lineal descendants. ${ }^{40}$ Finally, the ownership attribution rules of $\S 4946(a)(3)$ and (4) of the Code are applicable in terms of determining whether a person owns $20 \%$ of the voting power of certain entities that are substantial contributors. ${ }^{41}$

\section{B. Public Benefit Requirement Under Code \$ 501(c)(3) and Private Benefit Doctrine}

Over the years, there has been a sharp turn from the traditional donations to public art museums to the establishment of one's very own private art museum. ${ }^{42}$ A high-net-worth donor has a choice to make: create a private art museum or donate artworks to established public charities. Arguably, private art museums should be held to stringent interpretations and enforcement associated with the current rules because they confer such a large tax benefit, including in the form of a larger cap on charitable deductions under $\S 170(\mathrm{~b})$ of the Code ${ }^{43}$ for their wealthy donors/founders and their progeny.

\section{One's Own Private Art Museum}

Pursuant to $\S 501(\mathrm{c})(3)$ of the Code, an organization, whether a corporation, community chest, fund, or foundation that is "organized and operated exclusively for... educational purposes" may qualify for tax exemption. ${ }^{44}$ Another popular critique of private art museums is that wealthy art collectors who are donors/founders are exerting a tremendous amount of

${ }^{40}$ I.R.C. $\S 4940(\mathrm{~d})(3)(\mathrm{D})$.

${ }^{41}$ Id. I.R.C. $\S 4940(\mathrm{~d})(3)(\mathrm{E})$.

${ }^{42}$ E. Alex Kirk, The Billionaire's Treasure Trove: A Call to Reform Private Art Museums and the Private Benefit Doctrine, 27 FordHAM InTELL. PROP. MEDIA \& ENT. L.J. 869, 873-75 (2017).

${ }^{43}$ See discussion infra at 396-98.

${ }^{44}$ I.R.C. § 501(c)(3) (2012). Educational organizations must provide one of two services: “(a) [t]he instruction or training of the individual for the purpose of improving or developing his capabilities; or (b) the instruction of the public on subjects useful to the individual and beneficial to the community." Treas. Reg. §1.501(c)(3)-1(d)(3)(i) (2017); Goldsboro Art League, Inc. v. Comm'r, 75 T.C. 337, 343 (1980). Other examples of educational organizations include: "zoos, planetariums, and symphony orchestras.” Treas. Reg. § 1.501(c)(3)-1(d)(3)(ii), ex. (4).

Pitt Tax Review | ISSN 1932-1821 (print) 1932-1996 (online) DOI 10.5195/taxreview.2020.114 | http://taxreview.law.pitt.edu 
control over what is perceived by the public. ${ }^{45}$ The donors/founders' ability to set their own visions as a stage for public consumption means they have significant influence. ${ }^{46}$ Again, this misses the real issue: tax benefits are provided to donors/founders when the private operating foundations are not addressing an actual need directly related to their stated charitable purpose.

Reforms have mistakenly focused on details about donations, such as retention of all or a partial interest in artwork. ${ }^{47}$ One attempt to limit the ability of wealthy donors to exploit tax benefits through the donation of artwork is the Pension Protection Act of 2006 (the "2006 PPA"). Prior to the 2006 PPA, wealthy art donors could receive tax benefits by donating art over the course of many years while never handing over ownership of the artwork to a museum. ${ }^{48}$ Fortunately, with the 2006 PPA, Congress minimized this loophole by providing that donors of tangible personal property, such as artwork, must give up physical possession of the property. ${ }^{49}$ Failure to abide by the requirement of full relinquishment results in a risk that any previously claimed deduction, with interest, will be recaptured. ${ }^{50}$ Nevertheless, wealthy art donors now have utilized an alternative way to gain tax benefits while keeping control over donated artwork: the establishment of their own private operating foundation, which is the subject of this Article.

\section{Charitable Deductions and Public Charities Versus Private Foundations}

To understand the tax benefits associated with private operating status, one must understand the charitable deduction rules that apply. Pursuant to $\S 170$ (b) of the Code, certain percentage limitations apply to cap the amount of deductions for charitable contributions a donor makes during a taxable

\footnotetext{
${ }^{45}$ Carol Duncan, The Art Museum as Ritual, in The ARt of ART History: A Critical ANTHOlogy 424, 425 (Donald Preziosi ed., 2d ed. 2009).

${ }^{46}$ See id.

${ }^{47}$ See, e.g., Pension Protection Act of 2006, Pub. L. No. 109-280, § 1218, 120 Stat. 780 (2006).

${ }^{48}$ Cong. Research Serv., RL34608, TAX Issues Relating to Charitable Contributions AND ORGANIZATIONS 16 (2013).

${ }^{49} \mathrm{Id}$.

${ }^{50}$ Steven Rogers, Donate Your Art and Keep It Too: How the Government Subsidizes Art Collections for the Rich and What Congress Can Do About It, 40 S. ILL. UnIV. L.J. 45, 65 (2015).
}

Pitt Tax Review | ISSN 1932-1821 (print) 1932-1996 (online) DOI 10.5195/taxreview.2020.114 | http://taxreview.law.pitt.edu 
year, regardless of whether the donation is made in cash or other property. ${ }^{51}$ The charitable contribution deduction amount depends both on the type of property donated and the legal status of the tax-exempt organization to which it is donated. ${ }^{52}$ More often than not, an art collection is considered "capital gain property," and thus its donation results in advantageous tax treatment. The donor is allowed a deduction for the fair market value ("FMV") of the art collection, which likely has appreciated in value over the time it was owned. ${ }^{53}$ At the same time, the donor does not have to report and pay tax on any gain as he/she would if he/she had sold the art collection and then donated the money.

Under $\S 501(\mathrm{c})(3)$ of the Code, tax-exempt organizations able to take in tax-deductible donations are one of two types: either public charities or private foundations. ${ }^{54}$ Public charities take in donations from a large crosssection of the public and include, inter alia, churches, educational institutions and hospitals. In contrast, a private foundation "receives funds from a limited number of donors - frequently a single wealthy individual — and then invests or distributes those funds to other $\S 501(\mathrm{c})(3)$ organizations." 55 The maximum contribution for a non-cash gift to public charity is $50 \%$ of the taxpayers adjusted gross income ("AGI"), as opposed to a much smaller percentage of AGI for a non-cash gift to a private foundation. ${ }^{56}$ Notably, private foundations are subject to more stringent restrictions than public charities given they have a limited range of support and due to the ease in which donors can exert control over the foundation. ${ }^{57}$ In terms of capital gain contributions to private non-operating foundations, donors are limited to a $20 \%$ deduction of AGI, a deduction limited to their basis, and a five-year

\footnotetext{
${ }^{51}$ I.R.C. $\S 170(b)(1)$.

${ }^{52}$ See $\S 170(\mathrm{~b}) \&(\mathrm{e})$.

${ }^{53}$ See id. § 170(e); see also Treas. Reg. § 1.170A-8(d)(3) (2017) (discussing capital gain property and fair market value rules).

${ }^{54}$ I.R.C. $§ 501(\mathrm{c})(3)$.

${ }^{55}$ Michael Fricke, The Case Against Income Tax for Nonprofits, 89 ST. JoHN's L. REV. 1129, 1178 (2015) (citing I.R.C. § 509).

${ }^{56}$ I.R.C. $§ 170(b)(1)$.

${ }^{57}$ Internal ReVenue SeRV., DOMESTIC Private Found. (2013), https://www.irs.gov/pub/irssoi/2013privatefoundationsonesheet.pdf. See generally I.R.C. § 170(b)(1).
}

Pitt Tax Review | ISSN 1932-1821 (print) 1932-1996 (online) DOI 10.5195/taxreview.2020.114 | http://taxreview.law.pitt.edu 
carryforward period. ${ }^{58}$ At the same time, there are three main tax incentives associated with private foundations: (1) a charitable contribution deduction each year a donation is made, (2) relief from capital gains tax on donated property, and (3) a lesser amount or elimination of estate taxes. ${ }^{59}$

\section{E. Advantages of Private Operating Foundations}

Private foundations are further separated into two types of organizations. First, there are non-operating foundations, which usually support charitable organizations through grants. ${ }^{60}$ Second, there are private operating foundations, and private art museums fall under this category. ${ }^{61}$ Private operating foundations are tax-exempt organizations that "directly" use their assets or income to "the active conduct of the activities" comprising the charitable or educational purpose "for which it is organized and operated." ${ }^{2}$ From a tax incentive standpoint, a donor of an art collection would prefer to form a private operating foundation because they provide donors with greater limits in terms of tax deductions than a mere grantmaking (non-operating foundation).

\section{F. Five Advantages of Private Operating Foundations}

There are at least six benefits for private operating foundations, which are unavailable to non-operating foundations. First, charitable contributions to private operating foundations are deductible up to $50 \%$ of the taxpayer's adjusted gross income ("AGI"), compared to only $30 \%$ of the taxpayer's adjusted gross income in the context of a non-operating foundation in most

\footnotetext{
${ }^{58}$ I.R.C. $\S 170(\mathrm{~b})(1)(\mathrm{D})(\mathrm{i})-(\mathrm{ii})$.

${ }^{59}$ What Is a Private Foundation?, FOUND. SOURCE, https://www.foundationsource.com/learnabout-foundations/what-is-a-private-foundation/ (last visited May 2, 2020).

${ }^{60}$ I.R.S., Types of Foundations, https://www.irs.gov/charities-non-profits/private-foundations/ types-of-foundations (last visited May 2, 2020).

${ }^{61}$ See I.R.C. $\S 4942(j)(3)(A)$.

${ }^{62} \mathrm{Id}$.
}

Pitt Tax Review | ISSN 1932-1821 (print) 1932-1996 (online) DOI 10.5195/taxreview.2020.114 | http://taxreview.law.pitt.edu 
cases. ${ }^{63}$ Contributions of appreciated property, whether to a public charity or a private operating foundation, result in an up to $30 \%$ of AGI deduction. ${ }^{64}$ Second, old line foundations can avoid tax on their investment income if the three requirements detailed under the definition of a private operating foundation are met. ${ }^{65}$ Third, the minimum $5 \%$ of assets payout requirements do not apply because they are replaced by a less stringent income test. ${ }^{66}$ Fourth, the requirement that a grant from a private foundation must be spent in one year does not apply. ${ }^{67}$ Fifth, the tax on self-dealing imposed on private foundations does not apply. ${ }^{68}$ Sixth, instead of a basis deduction, a fair market value deduction is allowed for donated artwork. ${ }^{69}$

Private operating foundations are subject to some of the same restrictions that apply to nonoperating foundations, but overall this form is more lenient. ${ }^{70}$ Notably, they are not subject to the excise tax for failure to distribute income. ${ }^{71}$ Moreover, as stated above, they allow donors a higher cap on deductions. In fact, charitable contributions to private operating foundations are treated like donations to public charities. ${ }^{72}$ An operating

63 I.R.S., Charitable Contribution Deductions, https://www.irs.gov/charities-non-profits/ charitable-organizations/charitable-contribution-deductions (last visited May 2, 2020) (noting exception for private pass-through foundations.

${ }^{64}$ I.R.C. $\S 170(b)$.

${ }^{65}$ See I.R.C. $\S 4940(d)$.

${ }^{66}$ See Treas. Reg. $\S 53.4942(b)-1(c)$ for a description of the income test.

${ }^{67}$ See I.R.C. $\S 4942(\mathrm{~g})$.

${ }^{68}$ See I.R.C. $\S 4942(a)(1)$.

69 I.R.S., Private Operating Foundations, https://www.irs.gov/charities-non-profits/privatefoundations/private-operating-foundations (last visited Feb. 20, 2020) [hereinafter Private Operating Foundations]; see also, Barbara Benware, Contributing Appreciated Non-Cash Assets to Charity: Art, SCHWAB CHARITABLE, https://www.schwabcharitable.org/public/charitable/features/non_cash_ contribution_options/donate-noncash-assets-art.html (last visited May 2, 2020).

${ }^{70}$ See Private Operating Foundations, supra note 69.

${ }^{71}$ See I.R.C. $\S 4942(a)(1)$ and (b).

${ }^{72}$ See I.R.C. $\S 170(\mathrm{~b})(1)(\mathrm{A})(\mathrm{vii}) \&(\mathrm{~b})(1)(\mathrm{D})(\mathrm{i})$ (providing that contributions by individuals to operating foundations have a cap of $50 \%$ of the taxpayer's adjusted gross income as in the case of contributions to public charities); see also I.R.C. § 170(d)(1) (noting any excess of the 50\% cap may be carried forward); see also I.R.S., Exempt Organization Types, https://www.irs.gov/charities-nonprofits/exempt-organization-types (last visited May 2, 2020). Importantly, "[t]he [2017 Tax Cuts and Job Act] boosted the cap to 60 percent of AGI [for cash donations], and the [Coronavirus Aid, Relief, and

Pitt Tax Review | ISSN 1932-1821 (print) 1932-1996 (online) DOI 10.5195/taxreview.2020.114 | http://taxreview.law.pitt.edu 
foundation can receive qualifying distributions, counting toward the distribution requirement, from a private foundation as long as it is not controlled by it. ${ }^{73}$

\section{G. Private Inurement and Private Benefit Doctrine}

Private art museums raise both private inurement and private benefit issues that apply to both types of private foundations. In order to avoid running afoul of the Code's restriction on private inurement, a private foundation must ensure "no part of [its] net earnings inures to the benefit of any private shareholder or individual ..."74 Typical examples of private inurement include the following:

(1) the private foundation pays a private shareholder or individual too much for property given or services provided to it; or

(2) a private shareholder or individual pays the private foundation too little for the economic value received. ${ }^{75}$

In sum, private inurement occurs when someone close to the charity steals from it. ${ }^{76}$ Private benefit is different, and the rules are not centralized in the Code. The private benefit doctrine is also encapsulated in the Treasury Regulations, which provide: "An organization is not... [qualified for exemption] unless it serves a public rather than a private interest." Specifically, the foundation must show "that it is not organized or operated for the benefit of private interests such as designated individuals, the creator

Economic Security] CARES Act eliminates the cap entirely for 2020." Howard Gleckman, How the CARES Act Increases Charitable Deductions Without Helping Non-Profits Very Much, TAX POL'Y CTR. (Apr. 8, 2020), https://www.taxpolicycenter.org/taxvox/how-cares-act-increases-charitable-deductionswithout-helping-non-profits-very-much.

${ }^{73}$ See I.R.S., Qualifying Distributions-In General, https://www.irs.gov/charities-non-profits/ private-foundations/qualifying-distributions-in-general (last viewed May 2, 2020).

${ }^{74}$ I.R.C. $§ 501(\mathrm{c})(3)$. Private shareholder or individual is defined as "persons having a personal and private interest in the activities of the organization.” Treas. Reg. $\S 1.501(\mathrm{a})-1(\mathrm{c})$.

${ }^{75}$ See John D. Colombo, Using Donations to Set the Boundaries of Charitable Tax Exemption, NYU NAT'L CTR. ON PhILANTHROPY \& L. ANN. CONF. PROC. 1, 38 (2015).

${ }^{76}$ Kirk, supra note 42 , at 888.

${ }^{77}$ Treas. Reg. § 1.501(c)(3)-1(d)(1)(ii).

Pitt Tax Review | ISSN 1932-1821 (print) 1932-1996 (online) DOI 10.5195/taxreview.2020.114 | http://taxreview.law.pitt.edu 
or his family, shareholders of the organization, or persons controlled, directly or indirectly, by such private interests." 78 As tax scholars have noted, private benefit is assessed on a case-by-case basis and involves weighing various factors. ${ }^{79}$

\section{THE INCEPTION OF THE GETTY CENTER ILLUSTRATES THE PROBLEMS}

In order to meet the annual spending requirement, from 1981 to 1983 , the President of the Getty Trust, Harold Williams, and his later wife Nancy Englander brainstormed a type of charity conglomerate that was between a museum and a university. ${ }^{80}$ The goal was to establish an institution that could spend the income from the Getty Trust in perpetuity. If one stops there, the problem becomes apparent. Rather than focusing on a perceived societal need, the focus was shifted to how to use up the enormous amount of investment income each year. ${ }^{81}$ Unfortunately, the current private operating foundation rules do not address this dilemma. There has been too much focus on private inurement and private benefit doctrine, which although valid, do not consider whether the way officers and directors even conceive of the charitable purpose is within the bounds of our tax-exempt laws. When the former President of the Getty Museum commissioned legendary architect Richard Meier to build a modern campus for the "hybrid institution" on a hilltop overlooking both the Pacific Ocean and Los Angeles, it was clear the bill, initially projected at 100 million dollars but later closer to one billion dollars, would take care of the "problem" of expending the investment income of the Getty Trust. ${ }^{82}$

\section{A. Misconceptions, Missed Prosecutions, and Misapplications Associated with Private Operating Foundation Rules}

This history makes it seem as if the main and perhaps only purpose of the Getty Center was to meet the expenditure requirements of a tax-exempt

\footnotetext{
${ }^{78}$ Id.; see also John D. Colombo, In Search of Private Benefit, 58 FLA. L. REV. 1063, 1067 (2006).

${ }^{79}$ See Colombo, supra note 75, at 1072-73.

${ }^{80}$ See Norman, supra note 23.

${ }^{81}$ See id. (describing the resulting institution as "created out of thin air in order to spend Getty's money in conformity with U.S. tax laws").

${ }^{82}$ See id.
}

Pitt Tax Review | ISSN 1932-1821 (print) 1932-1996 (online) DOI 10.5195/taxreview.2020.114 | http://taxreview.law.pitt.edu 
charitable organization. If so, then one must wonder whether something has gone awry in how we interpret the requirement of being charitable for tax purposes. Does the Code require private operating foundations to spend money for the sake of spending it, as long as it is in furtherance of its charitable purpose? Alternatively, is the idea that since private operating foundations are fulfilling a need, that otherwise the government would have to meet, that justifies a tax subsidy? This part examines the history of the Getty Trust in greater detail to shed light on these questions.

Norman considers the normal growth cycle of an artistic or educational institution. She states, "[t]he normal life - cycle of artistic or academic institutions begins with a need, and follows up with an attempt to meet it; if the institution is perceived as useful, it will grow." ${ }^{, 33}$ The Getty Trust reverses this natural sequence. It starts out with an institution that has already attained heights that most institutions will not after decades of useful service. The problem is that the Getty Trust, including the Getty Center, was not constructed to meet any palpable need. ${ }^{84}$ As Norman states, "Williams and his 694 staff desperately want the trust to be useful, but it has not come into existence to meet any obvious need - except to spend the legacy." 85

The Getty Trust story suggests that a large endowment and staggering investment income divorced from a substantial charitable purpose other than to spend money, promotes the private inurement scandals that have plagued the Getty Trust. Some might think that the problem is located with unscrupulous officers or trustees/directors, but this article submits that it is instead a lack of real-life consequences for their misbehavior. The Getty Trust scandal of 2006 shows there are no real consequences for the misuse

${ }^{83} I d$.

${ }^{84} \mathrm{Id}$. Granted, preserving cultural heritage may be legitimate purpose tied to an overall educational purpose. However, one must consider who benefits from that preservation. Underrepresented segments of society do not because of the inaccessibility of the works and exhibits. Moreover, there is a long history of cultural looting associated with the Getty Trust's acquisitions. See Jason Felch \& Livia Borghese, Italy, Getty End Rift, L.A. Times (Sept. 26, 2007), https://www.latimes.com/archives/la-xpm-2007-sep-26-etgetty26-story.html (reporting the Getty Museum agreed to return 40 antiquities worth tens of millions of dollars to Italy per Italy's claim that the pieces purchased by Getty were looted and smuggled out of Italy). For a recent example of the Getty Trust's improper acquisitions, see Gaia Pianigiani, Italian Court Rules Getty Museum Must Return a Prized Bronze, N.Y. TIMES (Dec. 4, 2018), https://www.nytimes.com/2018/ 12/04/arts/design/getty-bronze-italy-ruling.html.

${ }^{85}$ See Norman, supra note 23.

Pitt Tax Review | ISSN 1932-1821 (print) 1932-1996 (online)

DOI 10.5195/taxreview.2020.114 | http://taxreview.law.pitt.edu 
of funds of a private operating foundation because an enforcement action was never even filed. ${ }^{86}$ The law is on the books to prevent such misconduct, but it is not resulting in an enforcement action or a prosecution in even the most egregious cases.

In terms of the other restrictions on compensation or expenditure of funds for charitable purposes, the Getty Trust example evinces a laissez faire approach to less serious infractions. For example, the bounds of reasonable compensation are commonly stretched in the world of private art museums. ${ }^{87}$ The Getty Trust improperly used charitable funds to purchase artwork for retiring trustees who are to serve without compensation. ${ }^{88}$ The Getty Trust also paid a former Getty Museum director $\$ 3$ million according to published reports, which still was found to be reasonable. ${ }^{89}$ Charitable funds may be used for restitution in association with fraudulent misdeeds involving other countries and their artwork..$^{90}$ On some level, it is not the private operating foundation rules themselves that need reform but rather how those rules are interpreted and carried out that will result in necessary change. Reform in this area is timely given the proliferation of private art museums and their enormous endowments and vast sums of investment income.

A looming issue is whether oversaturation of charitable activity to a narrowly tailored group should be subsidized through private operating foundations like the Getty Trust. Section 4942(j)(3) of the Code provides that

${ }^{86}$ See Neil Brodie \& Blythe Bowman Proulx, Museums Malpractice as a Corporate Crime? The Case of the J. Paul Getty Museum, 37 J. CRIME \& JUST. 399, 412 (2014).

${ }^{87}$ See, e.g., Rick Carroll, Aspen Art Museum Exec Makes More than Heads of Guggenheim, Denver Art Museum, ASPEN TiMES (Nov. 21, 2014), https://www.aspentimes.com/news/aspen-art-museum-execmakes-more-than-heads-of-guggenheim-denver-art-museum/; Philip Boroff, Museum of Modern Art Reveals Glenn Lowry's Whopping \$2.1 Million Pay Amid Staff Protest Over Benefit Cuts, ARTNET News (June 4, 2015), https://news.artnet.com/art-world/glenn-lowrys-2-1-million-package-revealed-304820; and Alan Zarembo \& Mike Boehm, Behind Michael Govan's Almost \$1-million LACMA Salary, L.A. TIMES (Aug. 18, 2009), https://www.latimes.com/entertainment/arts/la-et-lacma18-2009aug18-story .html.

${ }^{88}$ See, e.g., Press Release, Cal. Dep’t of Just., Attorney General Lockyer Issues Report Criticizing Getty Trustees, Former President Munitz for Improper Spending and Legal Violations (Oct. 2, 2006), https://oag.ca.gov/news/press-releases/attorney-general-lockyer-issues-report-criticizing-getty-trusteesformer; see also infra 407-08.

${ }^{89}$ See id., see also infra at 411.

${ }^{90}$ See Pianigiani, supra note 84.

Pitt Tax Review | ISSN 1932-1821 (print) 1932-1996 (online) DOI 10.5195/taxreview.2020.114 | http://taxreview.law.pitt.edu 
private operating foundation distributions must be directly for activity comprising the purpose or function for which the foundation is organized. ${ }^{91}$ Pursuant to $\S 4942(\mathrm{~g})(1)(\mathrm{B})$ of the Code, a qualifying distribution is defined as "any amount paid to acquire assets used (or held for use) directly in carrying out one or more" charitable purposes generally speaking. ${ }^{92}$ Private operating foundations must distribute at least two-thirds of their minimum investment return, whereas a non-operating foundation is required to distribute at least $5 \%$ of its assets. ${ }^{93}$ Nevertheless, if one examines the historical treatment of the Getty Trust, it becomes apparent that these restrictions and others are not being carried out within the spirit of the law because there is an oversaturation of charitable activity that is tailored to, and accessible only by, a narrow class.

\section{B. Subsidizing Saturation Versus Underserved Areas and Groups}

A commonly voiced complaint about private art museums is that they often bear significant proximity to public museums that are funded by a local government. For example, the Los Angeles County Museum of Art is approximately twelve miles from the Getty Center and holds the title of the largest museum in the Western United States. ${ }^{94}$ If one of the purposes of the deduction is to subsidize activity in order to relieve the government from doing so, it makes little sense to allow a deduction for a private museum located next to a governmental one. At least one court has held that the distance to existing government funded art museum was a factor in determining tax-exempt status. ${ }^{95}$ Another frequently cited problem is public

${ }^{91}$ I.R.C. $\S 4942(\mathrm{j})(3)$.

${ }^{92} \mathrm{Id} . \S 4942(\mathrm{~g})(1)(\mathrm{B})$.

${ }^{93} I d . \S 4942(\mathrm{j})(3),(\mathrm{e})(1)$.

${ }^{94}$ See About LACMA, https://www.lacma.org/about (noting LACMA has "a collection of more than 142,000 objects that illuminate 6,000 years of artistic expression across the globe"); see also David Farley, 6 Best Art Museums in Los Angeles, NEwsweEK (July 23, 2019), https://www.newsweek.com/6best-art-museums-los-angeles-1450760 (listing addresses of LACMA and the Getty Center and distance between the two via Google Maps).

${ }^{95}$ See generally Cleveland Creative Arts Guild v. Comm'r, 50 T.C.M. (CCH) 272 (1985) (holding that a creative arts guild that hosts art festivals could claim tax-exempt status even though they retained some sales proceeds from events because the art festivals furthered public appreciation of the arts in a community that is situated thirty miles from the nearest gallery or museum).

Pitt Tax Review | ISSN 1932-1821 (print) 1932-1996 (online) DOI 10.5195/taxreview.2020.114 | http://taxreview.law.pitt.edu 
accessibility. If private art museums are at the end of unmarked roads with no signs to direct potential visitors, they are providing little benefit to the public. ${ }^{96}$ Similarly, if they are only open during working hours and not on the weekend, many will be prevented from visiting. ${ }^{97}$

Yet, physical proximity is not the real issue. As explained above, people belonging to distinct groups simply lack access. The Getty Trust makes its art "public" but only within the letter of the law and not in terms of the vast differences in our society between those who have access to the impressive art collection of the Getty Center or art educational programs and those who do not. ${ }^{98}$ There are a number of artistic and educational endeavors that comport with the Getty Trust's charitable purpose but that also meet a measurable need. The problem with the Getty Center is not that it is inaccessible in terms of location, ${ }^{99}$ but it is inaccessible in terms of socioeconomic class, age, and life circumstance. Given the Getty Trust's stated aim of art history education, it would be appropriate for it to educate those students who have little or no background in art history education, in addition to those who are scholars in it. First, underprivileged schools that lack funding to hire teachers experienced in art history represent a group that needs the type of education that the Getty Trust is providing primarily to the elite on weekends and through global programming. A school field trip to the Getty Museum is not enough. Second, patients in hospitals and nursing homes around the country do not have access to grandiose art collections. Third, courthouses are another venue where the art could be displayed and

\footnotetext{
${ }^{96}$ See Rogers, supra note 50.

${ }^{97} I d$.

${ }^{98}$ To their credit, the Getty Center and the Getty Villa provide the "Arts Access" program for "more than 160,000 K-12 students" each year. As part of this program, the museums provide a one-hour guided tour with a skilled educator for free. See Getty, Arts Access, https://www.getty.edu/education/teachers/ trippack/index.html (last visited July 16, 2020). In addition, the Getty Center offers programs throughout the year that include free talks with prominent artists, thinkers, and scholars. It also offers courses, performances, film series, and experimental theatre. See Getty, Public Programs, https://www.getty.edu/ museum/programs/ (last visited July 16, 2020). However, these initiatives are not enough because most of even these cultural offerings are still inaccessible to systemically disempowered people as discussed.

${ }^{99}$ See Getty, About the Getty: Who We Are, https://www.getty.edu/about/whoweare/ (last visited Apr. 29, 2020) (discussing how The Getty Museum was established in J. Paul Getty's ranch home).
}

Pitt Tax Review | ISSN 1932-1821 (print) 1932-1996 (online) DOI 10.5195/taxreview.2020.114 | http://taxreview.law.pitt.edu 
observed by a greater portion of the public. ${ }^{100}$ Thousands of litigants, poor and rich, enter into courthouses all over the country every year. By requiring a certain percentage of the investment income to be spent in these areas, the government could direct these vast resources to a need within the stated charitable purposes of private operating foundations and private art museums.

Clearly, the investment income of the Getty Trust exceeds the amount needed to achieve its stated purpose, which as stated earlier is the "diffusion of artistic and general knowledge." Essentially, the officers are coming up with ways to spend the money without a regard to need. Thus, a cap on the amount spent on programs that benefit such a small percentage of people may be in order. Alternatively, these foundations could be required to expend a minimum amount of the overall yearly requirement on addressing underserved segments of the population, meaning those who cannot or do not travel to museums, whether here or abroad.

As an examination of the 2006 Getty Trust scandal discussed below shows, the private inurement restriction is only marginally enforced and therefore does not serve as a deterrent. One would expect private inurement because of the staggering size of the endowment, inner circle of officers, etc. However, similar to most white-collar crimes, the violations of the law were not prosecuted and that is problematic because a failure to enforce the law encourages further abuse at a time when IRS enforcement staff is already outnumbered. ${ }^{101}$

\section{PARDONING PRIVATE INUREMENT AND TURNING A BLIND INTERPRETIVE EYE TO OTHER MISCONDUCT}

One proposal is that art donors should have less control over boards and hold fewer director positions. ${ }^{102}$ This article argues that is not the real problem with private inurement. A concerning problem is the failure to

\footnotetext{
${ }^{100}$ Granted, the testator's wishes are an important limitation on how gifts may be used. See, e.g., In re Barnes Foundation, 2004 WL 2903655 at 1, 19 (Pa. O.C. 2004). At the same time, this is a fact sensitive analysis. For example, temporary loans of artwork, online exhibits, or rotating exhibits may not defeat a testator's stated wishes.

${ }^{101}$ See, e.g., Press Release, supra note 88.

${ }^{102}$ Rogers, supra note 50.
}

Pitt Tax Review | ISSN 1932-1821 (print) 1932-1996 (online) DOI 10.5195/taxreview.2020.114 | http://taxreview.law.pitt.edu 
enforce the private inurement restrictions set forth in the Code. Four years prior to the 1969 Act, the 1965 Treasury Report cautioned that private foundations "represent dangerous concentrations of economic and social power." 103 A major criticism of our federal tax system, which is evident in the proliferation of scholarly articles proposing a wealth tax, is that our tax policy "reinforces power, influence, and inequality" in our society. ${ }^{104}$ These problems become even more self-evident when wealthy donors are able to create and then donate to their own private art museum, which they also control, and then pass down the same ability to the next generation. ${ }^{105}$ There is a palpable unfairness associated with permitting "the founder and the founder's family to select the objects of their charitable bounty and to manage the charitable assets." "106 The greater injustice is private inurement and the failure to enforce restrictions against it through enforcement actions.

\section{A. Getty Scandal Involving Officer/Governing Body in 2006}

Undoubtedly, multi-million dollar private art museums invite private inurement. Given that reality, this Article argues that the question becomes one of enforcement instead of reform. Perplexingly, even some of the most egregious cases of private inurement in the private art museum world have failed to result in any known enforcement action.

One of the most notorious scandals involving the Getty Trust involved its ex-president Dr. Barry Munitz and private inurement. In 2006, Attorney General Bill Lockyer issued a report finding that Dr. Munitz had violated his legal duty by instructing Getty Trust employees to run personal errands. ${ }^{107}$ The report also stated that the trustees impermissibly used charitable funds to pay for travel expenses for Dr. Munitz's wife and to buy artwork as gifts for retiring board members. ${ }^{108}$ Regarding the latter, the report found the

\footnotetext{
${ }^{103} I d$.

${ }^{104}$ Alice Gresham Bullock, Taxes, Social Policy and Philanthropy: The Untapped Potential of Middle-and-Low Income Generosity, 6 CORNELL J.L. \& PUB. POL'Y 325, 330 (1997).

${ }^{105}$ See id.

${ }^{106}$ See id.

${ }^{107}$ Press Release, supra note 88.

${ }^{108}$ Id.
}

Pitt Tax Review | ISSN 1932-1821 (print) 1932-1996 (online) DOI 10.5195/taxreview.2020.114 | http://taxreview.law.pitt.edu 


\section{8 |Pittsburgh Tax Review | Vol. 172020}

"Getty trustees improperly allowed the use of more than $\$ 21,500$ in charitable funds to buy gifts of artwork for retiring trustees, who are supposed to serve without compensation." 109 In addition, the trustees approved firstclass travel, including overseas, luxury hotels, and five-star dinners for Dr. Munitz, which was outside the bounds of reasonable expenses. ${ }^{110}$

Attorney General Lockyer reasoned that since charitable organizations are subsidized by taxpayers, "they must at all times spend money lawfully and to further their charitable purposes." $111 \mathrm{He}$ also noted it is incumbent upon board members and executives to ensure funds are spent on charitable purposes and in fact they have a legal duty to do so. ${ }^{112}$ Not only did Dr. Munitz violate his duty to the charity, but also the trustees did not live up to their job as the governing body. ${ }^{113}$

Dr. Munitz compensated the charity for the improper benefits it had provided him, and the trustees put reforms in place. Also, Attorney General Lockyer appointed a former Attorney General to provide oversight to ensure the reforms were actually "implemented and compliance occurred." 114 One must ask though whether these consequences really serve as a deterrent to other private art museums already engaging in transactions that wave the private inurement flag.

Ultimately, Dr. Munitz paid \$250,000 in cash and more than two million dollars in forfeited benefits to settle the infractions, and this amount exceeded the amount misappropriated. ${ }^{115}$ The Attorney General did not file an enforcement action, citing Dr. Munitz's payments to the Trust and the agreement to put reform procedures in place to prevent future abuse. ${ }^{116}$

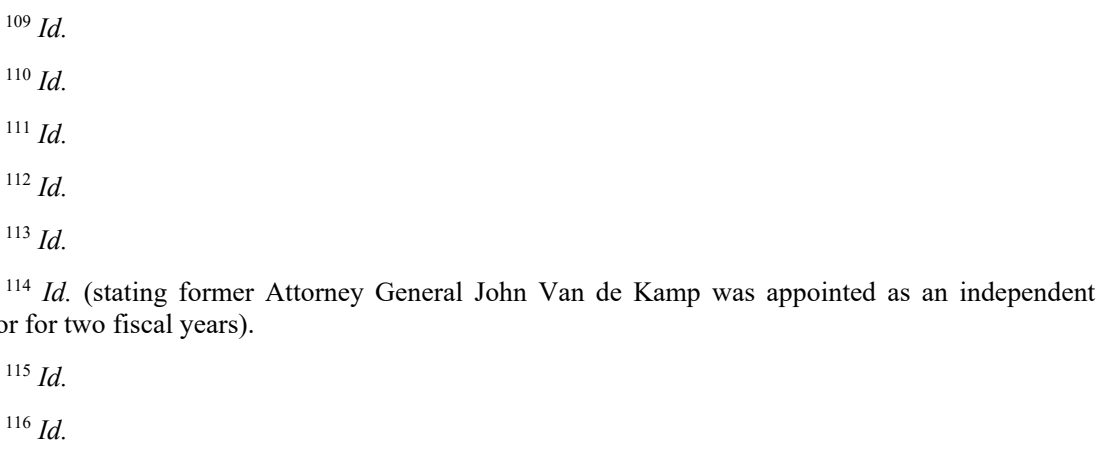

Pitt Tax Review | ISSN 1932-1821 (print) 1932-1996 (online) DOI 10.5195/taxreview.2020.114 | http://taxreview.law.pitt.edu 
If one of the reasons for punishment is to deter others from engaging in similar conduct, the Attorney General's treatment of the Getty scandal fails. Even though Dr. Munitz stole more than at least a six-figure sum from the charity, there was no action filed, and he was not prosecuted. The equivalent scenario would mean that as long as an embezzler returned the money, he/she would not be prosecuted. Even worse, at least in the embezzler scenario, the exact same individuals wronged are directly compensated. However, in the charitable context, it is a crime against the general body of taxpayers.

\section{B. Current Limitation on Substantial Contributors and Family Members Serving as Governing Body}

The current rules, at least as far as those concerning private operating foundations formed after 1983, reflect some of the proposals that were already on the table prior to the 1969 Act. An important question is whether they are stringent enough. For example, the 1965 Treasury Report proposed that "after a foundation had been in existence for 25 years, no more than 25 percent of the foundation's governing body could consist of donors or related parties." 117 Today, a private operating foundation's governing body must be comprised of fewer than $25 \%$ of disqualified individuals and its governing body must represent the general public. ${ }^{118}$ The private art museum has to select directors other than the donor/founder and their family. ${ }^{119}$ Overall, it would prevent a single family from maintaining control over a private art museum throughout generations. ${ }^{120}$ The nepotism involved with private art museums again runs against the notion of fairness. Most Americans believe that nepotism is counter to the cultural values of egalitarianism and merit. ${ }^{121}$ However, this has not stopped private inurement or other questionable activities, including the defense of fraud-related lawsuits as addressed in the next section.

\footnotetext{
${ }^{117}$ See Rogers, supra note 50.

${ }^{118}$ See I.R.C. $\S 4940(d)(2)$.

${ }^{119}$ Id. I.R.C. $\S 4940(\mathrm{~d})(2)(\mathrm{C}),(\mathrm{d})(3)(\mathrm{B})$.

${ }^{120}$ See Rogers, supra note 50.

${ }^{121}$ Nepotism: Wrong for the Workplace?, NPR MORNING ED. (Oct. 17, 2007), http://www.npr.org/ templates/story/story.php?storyId=15353609.
}

Pitt Tax Review | ISSN 1932-1821 (print) 1932-1996 (online) DOI 10.5195/taxreview.2020.114 | http://taxreview.law.pitt.edu 


\section{0 |Pittsburgh Tax Review | Vol. 172020}

\section{Subsidizing International Fraudulent Activity}

Although it is unclear why the Getty Trust engaged in the art purchases described below that resulted in lawsuits, arguably the pressure to spend the investment income was at least partly to blame. The resulting expenditure on legal fees to defend the actions of board members and officers is not one that is within keeping with the idea of why these foundations are allowed a subsidy. The lack of reprimand for spending charitable funds on lawsuits due to avoidable bad behavior at best, and at worst fraud, encourages such behavior. For example, the Getty Trust's payment of legal fees associated with Italian art restitution claims was deemed acceptable. ${ }^{122}$ If there was an additional tax on the charity for this behavior instead or an enforcement action, the governing board and officers would perhaps focus on spending the money in legitimate forums that benefit more diverse sections of the public, whether here or abroad.

\section{Unreasonable Compensation for Services}

The story of the Getty Trust shows that even if private operating foundations are investigated on other issues, such as private inurement, their misconduct in terms of excessive salaries to private art museum employees will be deemed appropriate. A solution would be to limit the ability of private operating foundations to pay compensation for services to substantial contributors and their families. ${ }^{123}$ Currently, a reasonable salary may be paid to disqualified persons, including substantial contributors and those related to them. ${ }^{124}$ The only requirement is that the compensation is necessary to carry out the exempt purposes of the private operating foundation. ${ }^{125}$ Yet, the problem again is failure to enforce the current law. Even this low threshold is not being enforced or taken seriously.

The Getty Trust scandal is an example where the only misconduct taken somewhat seriously was outright stealing from the charity or private

\footnotetext{
${ }^{122}$ See Press Release, supra note 88.

${ }^{123}$ See Rogers, supra note 50, at 64.

${ }^{124}$ See id.

${ }^{125} \mathrm{Id}$.
}

Pitt Tax Review | ISSN 1932-1821 (print) 1932-1996 (online) DOI 10.5195/taxreview.2020.114 | http://taxreview.law.pitt.edu 
inurement. Many of the Getty Trust's other transactions in relation to the Getty Center were deemed appropriate. Overall, in terms of transactions involving the Getty Museum, the Getty Trust was not found to have acted improperly. ${ }^{126}$ For example, the salary paid to a former trustee for writing a history of the Getty was deemed reasonable. ${ }^{127}$ Also, the legal fees and costs paid in relation to trustee Barbara Fleischman's testimony and documentary evidence to Italian authorities in connection with the criminal investigation of a prior Getty Museum curator was deemed appropriate. ${ }^{128}$ The report failed to find a violation of fiduciary duty or abuse of discretion in the approval of severance payments for former Getty Museum director Deborah Gribbon and Dr. Munitz's former chief of staff, Jill Murphy, which were \$3 million and more than $\$ 350,000$ respectively. ${ }^{129}$

\section{ALTERNATIVE APPROACHES}

Currently, donors are entitled to deduct up to $50 \%$ of their AGI for charitable contributions to private art museums as explained earlier. ${ }^{130} \mathrm{~A}$ possible solution to the problem of fairness and self-dealing may be to lower the amount that wealthy donors may deduct. ${ }^{131}$ This would promote a notion of fairness given their ability to maintain control over "donated" artwork. ${ }^{132}$ Instead of focusing solely on whether the expenditures of a private art museum are directly related to its charitable purpose, there should be some consideration of a cap that applies before the private art museum must be compelled to spend its money on some other encapsulation of its stated charitable purposes, specifically art education, that targets the underserved or a more broad base of the public. Again, taking the Getty Trust as an example and its required exorbitant expenditures, this problem becomes selfevident.

\footnotetext{
${ }^{126}$ See Press Release, supra note 88.

${ }^{127} I d$.

${ }^{128} \mathrm{Id}$.

${ }^{129} \mathrm{Id}$.

${ }^{130}$ See supra note 56.

${ }^{131}$ See Rogers, supra note 50, at 66-67.

${ }^{132}$ See id.
}

Pitt Tax Review | ISSN 1932-1821 (print) 1932-1996 (online) DOI 10.5195/taxreview.2020.114 | http://taxreview.law.pitt.edu 


\section{2 |Pittsburgh Tax Review | Vol. 172020}

\section{CONCLUSION}

Traditional criticisms of private art museums have missed the mark. The real problem with these private operating foundations is that they entitle wealthy donors/founders, their progeny and their connections to extremely favorable tax benefits while over-saturating the need for art education and limiting such art education to only select segments of the population. Additionally, as repositories of vast sums of money, these private art museums seem to invite private inurement, as the 2006 Getty scandal shows. At the same time, given the lack of enforcement of rules to prevent inurement, there is no real deterrence to future bad behavior. In terms of reform, private art museums should be compelled to spend money on additional forms of art education, and the rules on the books must be enforced to result in real world consequences and thus deterrence.

Pitt Tax Review | ISSN 1932-1821 (print) 1932-1996 (online) DOI 10.5195/taxreview.2020.114 | http://taxreview.law.pitt.edu 